Earth Syst. Dynam. Discuss., doi:10.5194/esd-2016-27, 2016

Manuscript under review for journal Earth Syst. Dynam.

Published: 1 August 2016

(c) Author(s) 2016. CC-BY 3.0 License.

\title{
Regional climate change projections for the Barents region
}

\author{
Andreas Dobler ${ }^{1}$, Jan Erik Haugen ${ }^{1}$, and Rasmus Emil Benestad ${ }^{1}$ \\ ${ }^{1}$ The Norwegian Meteorological institute, PO Box 43 Blindern, NO-0313 Oslo, Norway \\ Correspondence to: Andreas Dobler (andreas.dobler@met.no)
}

Abstract. Regional climate models can provide estimates for quantities that are difficult to study in empirical studies, such as cloud cover, wind, sea-ice or dependencies between variables. In this study, the regional climate model COSMO-CLM was used to simulate local climate conditions over the Barents region and provide projections for the three emission scenarios RCP2.6, RCP4.5 and

5 RCP8.5. The results indicate that the most pronounced local warming can be expected in winter in the high Arctic near the present sea-ice border. The changes reach up to $20 \mathrm{~K}$, resulting in future temperatures close to melting. Similar spatial patterns are seen for changes in precipitation and wind in all scenarios, but with different amplitudes. Precipitation sensitivities, however, show the highest values along the west coast of Norway and in the Arctic during summer. For clouds, the projections show a decrease in winter mean cloud cover over sea and an increase over land, dominated by changes in low layer clouds. Over the Barents sea, convective cloud fraction is projected to increase, together with an increases in convective and total precipitation. In contrast to the COSMO-CLM and two other regional climate models taken into account, the ensemble mean of the driving global models shows an increasing trend in total cloud cover over the Barents sea. An analysis of the opposing trends reveals that there is an added value in the regional climate model projections for the Barents region.

\section{Introduction}

One by-product from use of fossil fuels is the increase in the atmospheric concentration of carbon dioxide $\left(\mathrm{CO}_{2}\right)$ and an associated global warming (IPCC, 2013). Over the Arctic, the warming has been more pronounced than for the rest of the globe due to the "polar amplification" (Manabe and Stouffer, 1980; Screen and Simmonds, 2010) which is expected to continue in a warmer future climate (IPCC, 2013). Furthermore, a climate change is expected to affect the weather statistics in 

and maximum temperatures and storms (Hassol, 2005; Vikhamar-Schuler et al., in press; Benestad et al., 2016).

While there is increasing amounts of information about some variables, such as temperature and precipitation (Hassol, 2005; Dicks et al., 2013; Benestad et al., 2016), there are others for which little is known, for instance changes to the cloud climatology, type of precipitation and wind speeds. It is interesting to study how these various aspects are related, both because such dependencies will provide information about the aggregated effect of physical processes and because they may be used to estimate an unobserved quantity if there is a dependency with an observed variable.

Regional climate models (RCMs) are appropriate tools for studying such dependencies between different quantities, especially when non-linear processes are present which are difficult to model empirically, for instance interactions between temperature and precipitation. RCMs are also able to provide more data than empirical-statistical downscaling methods, both in terms of different physical quantities as well as in terms of the spatio-temporal extent. Furthermore, despite some limitations in simulating the current climate (e.g., Kotlarski et al., 2014), RCMs are believed to provide plausible projections for the future, particularly when simulating changes relative to a reference climate, and thus to provide valuable information about future climate changes (Rummukainen, 2010).

40 However, even with a perfect model and setup, it is not possible to account for the complete possible range of future outcomes due to natural and internal variability (Deser et al., 2012). Already a proper estimate of the possible range needs a large ensemble of simulations, which would result in a very high computational demand using RCMs only. In this aspect, empirical-statistical methods are much better suited. Benestad et al. (2016) carried out empirical-statistical downscaling of a large ensemble of global models for the Barents region. Their study includes information on possible ranges in future temperature, precipitation and storms, and provides the possibility to locate our results within this range and to compare them to an alternative downscaling approach.

While there is a substantial number of RCM projections available over Europe from the ENSEMBLES project (Hewitt, 2004) and the Coordinated Regional Climate Downscaling Experiment (CORDEX, Giorgi et al., 2009; Jones et al., 2011), the Barents region lies outside those simulation domains. Thus, only a few runs driven by current CMIP5 scenarios are available covering the area (Koenigk et al., 2015). This study is therefore also a contribution to increasing the ensemble of simulations for the Barents region based on different RCMs and driving global models, and thus provide additional confidence and insights in the projected changes for the region.

55 Furthermore, Koenigk et al. (2015) showed that a projected decrease in total cloud cover over the arctic in RCM simulations is inconsistent with an increase in the driving global earth system models (ESMs). Thus, an interesting question is whether this finding is specific to the particular RCM used in Koenigk et al. (2015) or if it is typical for dynamically downscaled results. We provide additional 
Earth Syst. Dynam. Discuss., doi:10.5194/esd-2016-27, 2016

Manuscript under review for journal Earth Syst. Dynam.

Published: 1 August 2016

(c) Author(s) 2016. CC-BY 3.0 License.

The remainder of this paper includes section 2, which describes the COSMO-CLM model and its setup used in the present study. Section 3 shows results from the evaluation carried out for the historical RCM simulations, focusing on sea-ice, temperature and precipitation. In section 4 we will present and discuss projected changes in temperature, sea-ice, precipitation (including precipitation sensitivities), wind and the projected changes related to cloud climatologies. Finally, section 5 will provide a summary and conclusions of our new projections and relate them to earlier findings.

\section{Model and model setup}

We've carried out four scenario runs with the regional climate model (RCM) COSMO-CLM (Rockel et al., 2008) at a grid-resolution of $0.22^{\circ}(\approx 25 \mathrm{~km})$ covering large parts of Scandinavia, the Barents region and Svalbard. The runs cover the three representative concentration pathways (RCPs, Moss et al., 2010; van Vuuren et al., 2011) RCP2.6, RCP4.5 and RCP8.5 and have been driven by two different global earth system models (ESMs), the MPI-ESM-LR model (Giorgetta et al., 2013) for RCP2.6, RCP4.5 and RCP8.5 and the EC-EARTH model (Hazeleger et al., 2012) for RCP4.5.

The COSMO-CLM is a non-hydrostatic RCM based on the COSMO (Consortium for Small-scale Modeling) numerical weather prediction (NWP) model (http://www.cosmo-model.org). For our climate projections, we have applied the COSMO-CLM (version 131108_5.00_clm6) for the two time slices 1968-2000 and 2068-2100 in a North European domain covering large parts of Scandinavia, the Barents sea and parts of the Arctic Ocean. To account for spin-up, the first 3 years of the simulations are neglected and the analysis is limited to the time periods 1971-2000 and 2071-2100. Details on the COSMO-CLM model can be found on the CLM web page http://www.clm-community.eu/. The main differences between the NWP and RCM version are explained in Böhm et al. (2006). Vertically, the model domain consists of 40 atmospheric layers (using height-based hybrid Gal-Chen coordinate) reaching up to $22700 \mathrm{~m}(\approx 40 \mathrm{hPa})$ and 9 soil layers down to $11.5 \mathrm{~m}$ using a multilayer soil model (Schrodin and Heise, 2002).

Our model configuration follows the setup used for simulations covering Europe (Jacob et al., 2013; Kotlarski et al., 2014). This configuration includes a radiation scheme following (Ritter and Geleyn, 1992), the Tiedtke (Tiedtke, 1989) convection scheme and a Kessler-type (Kessler, 1995) micro-physics scheme with ice-phase processes for cloud water, rain and snow. Numerical integration was done by a third order Runge-Kutta scheme with a time step of 120 s.

Note that in the COSMO-CLM runs, the sea surface temperature and concentration of sea-ice is specified by the driving global model. Although the global models include an ocean model with a higher spatial resolution than the atmospheric part, the resolution is still coarser than in the RCM. This is taken into account by interpolating the global data to the RCM grid and land-sea mask. 
Earth Syst. Dynam. Discuss., doi:10.5194/esd-2016-27, 2016

Manuscript under review for journal Earth Syst. Dynam.

Published: 1 August 2016

(c) Author(s) 2016. CC-BY 3.0 License.

\section{Evaluation} the MPI-ESM-LR driven run (not shown). Furthermore, the results are in good agreement with the ERA-Interim driven COMSO-CLM simulations shown in Kotlarski et al. (2014) over the common parts of the domain.

110 Figure 1 shows the seasonal sea-ice cover for the observations and the COSMO-CLM driven by MPI-ESM-LR and EC-EARTH. The EC-EARTH run shows too much sea-ice in the Barents sea for all seasons. The MPI-ESM-LR run produces a sea-ice cover that resembles the observations, both in its extent and the annual variability. However, it simulates a too large sea-ice cover north of Svalbard and west of Novaya Zemlya. Koldunov et al. (2010) have found similar results for the ECHAM5summer, both runs show a too low number of years covered by sea-ice for the Arctic and especially the EC-EARTH driven run shows a too large annual variability. For monthly means, the MPI-ESMLR driven run shows results with similar deviations as for the seasonal means (not shown).

The temperature biases of the two historical COSMO-CLM runs compared to the CRU observations are shown in Fig. 2. The EC-EARTH driven run shows a tendency towards simulating a too cold climate, especially over Svalbard and Iceland. For the north tip of Novaya Zemlya and the coast of Finnmark, a small warm bias in winter can be seen. The run driven by the MPI-ESM-LR shows warm biases in the Russian parts of the domain (e.g., Novaya Zemlya) and the coast of Finnmark, with an exception of summer temperatures.

Precipitation biases are similar for both historical runs, with an underestimation in some coastal regions and a general overestimation otherwise (Fig. 3). In terms of relative biases, the largest overestimation can be found over Novaya Zemlya and the highest parts of the Scandinavian Mountains, showing more than $90 \%$ of overestimation (not shown).

Note that major biases occur in regions where station density is low, such as on Novaya Zemlya 
Earth Syst. Dynam. Discuss., doi:10.5194/esd-2016-27, 2016

Manuscript under review for journal Earth Syst. Dynam.

Published: 1 August 2016

(c) Author(s) 2016. CC-BY 3.0 License.

are contradicting, for instance too icy conditions in the MPI-ESM-LR run on Novaya Zemlya in connection with a too wet and warm climate. This indicates that in those regions the CRU data, due to the low station density, may not be well suited for an evaluation. As additional evaluation data, reanalysis products can be used. Lindsay et al. (2014) compared seven reanalysis products in the Arctic, and the MERRA (Rienecker et al., 2011) reanalysis has shown good results, both for precipitation and temperature. Furthermore, the MERRA reanalysis is available at a resolution close to the CRU observations $\left(0.625^{\circ} \times 0.5^{\circ}\right)$.

Comparing the MERRA reanalysis (years 1980-2000) to the CRU observations (Fig. 2 and 3) reveals differences similar to the COSMO-CLM MPI-ESM-LR run, namely generally higher temperatures than CRU in winter over the northern parts of the domain, lower temperatures in summer and enhanced precipitation in the Scandinavian Mountains and on Iceland. Compared with the ECEARTH driven run, the MERRA reanalysis shows generally higher temperatures, especially over Svalbard, and more precipitation in summer. The MPI-ESM-LR driven run gave larger ice extent west of Novaya Zemlya than the MERRA reanalysis and is consistent with colder and dryer conditions, i.e., a more continental climate. This is also in agreement with findings of Koldunov et al. (2010) who showed too cold conditions in the ECHAM5-MPIOM for too icy regions when compared to reanalysis data.

The differences in biases show that it is difficult to evaluate historical model simulations in remote areas such as the Arctic and uncertainties in evaluation data sets should be taken into account.

\section{Results and discussion}

\subsection{Temperature and sea-ice}

Figure 4 shows the seasonal temperature changes projected through the four RCM runs, and the largest changes in all runs can be seen in the northern part of the domain in winter, followed by autumn and spring. The summer temperature changes are smallest. The general changing pattern is very similar between the runs and differs mainly in the amplitude of changes. For the three MPIESM-LR driven runs, the climate change signal is strongest in the RCP8.5 scenario, followed by RCP4.5 and RCP2.6. The RCP4.5 run driven by EC-EARTH shows changes of the same magnitude as the RCP8.5 run driven by MPI-ESM-LR.

The maximum increases in temperature occur in the sea area between Novaya Zemlya and Svalbard, where a regularly ice-free sea (i.e., on more than $20 \%$ of the years) is established in the future period (2071-2100). For the EC-EARTH RC4.5 driven and the MPI-ESM-LR RCP8.5 driven run, the change is about $20 \mathrm{~K}$, with winter mean values for the future period of about $268 \mathrm{~K}$ and $273 \mathrm{~K}$, respectively (not shown). There is a prominent gradient in the temperature change over Svalbard from south-west to north-east, in agreement with other studies (Førland et al., 2009; Koenigk et al., 
Earth Syst. Dynam. Discuss., doi:10.5194/esd-2016-27, 2016

Manuscript under review for journal Earth Syst. Dynam.

Published: 1 August 2016

(c) Author(s) 2016. CC-BY 3.0 License.

The daily minimum and maximum temperature changes show almost identical patterns as the mean temperature increases, with about $0.2 \mathrm{~K}$ higher changes in the minimum temperature and about $0.2 \mathrm{~K}$ lower changes in the maximum temperature (not shown). Thus, the daily temperature range is projected to decrease by about $0.4 \mathrm{~K}$.

170 Looking at future sea-ice cover (Fig. 4), all sea areas included in our domain are projected to be regularly ice-free during summer in all scenarios (including RCP2.6) and during autumn in the EC-EARTH and MPI-ESM-LR RCP8.5 run. The complete Barents sea is projected to be regularly ice-free throughout the whole year in the EC-EARTH and MPI-ESM-LR RCP8.5 run, and only a small part is remaining in the MPI-ESM-LR RCP4.5 and RCP2.6 run.

\subsection{Precipitation}

In the four RCM projections, the patterns of changes in precipitation is similar to the temperature changes, and the order of the runs is the same. The largest relative precipitation changes again occur in the northern part of the domain in winter (accompanied by the sea-ice retreat) and the smallest changes occur in summer (Fig. 5).

Note that due to already high amounts of precipitation in the current climate along the Norwegian west coast, the relative changes (Fig. 5) are moderate but changes in absolute values are high (Fig. S1).

For precipitation sensitivity (i.e., the ratio of precipitation change and temperature change), the largest increases in the RCP8.5 run can be seen along the Norwegian west coast and in the Arctic in summer, both for absolute and relative changes (Figs. 6 and 7). For the other scenario runs, the patterns are similar, but with a reversed order: The highest sensitivities occur in the RCP2.6 run, the lowest in the EC-EARTH driven run (Fig. S2). Averaged over the domain, the sensitivity in RCP8.5 is about $4 \% / \mathrm{K}(2.4 \mathrm{~mm} / \mathrm{month} / \mathrm{K})$ in winter and about $3.3 \% / \mathrm{K}(1.9 \mathrm{~mm} / \mathrm{month} / \mathrm{K})$ in summer. In contrast, Koenigk et al. (2015) found higher summer than winter precipitation sensitivities using the RCM RCA (Jones et al., 2004; Samuelsson et al., 2011) in its newest version (RCA4). However, their focus was on the Arctic, and the parts of the Arctic included in our simulations show higher summer than winter sensitivities as well.

\subsection{Wind}

The biggest changes in maximum daily $10 \mathrm{~m}$ wind speeds are projected in winter and show a strong relationship to the sea-ice retreat (Fig. 8). There is a pronounced increase of the maximum daily winds, where the sea-ice disappears and a decrease in the already sea-ice free parts of the Barents sea. All scenarios show similar patters (not shown). For Svalbard, this results in an increase on the north-eastern coast, a decrease on the south-western coast and the mainland being in a transition zone with only small changes. The RCP8.5 run shows increases of up to $3.5 \mathrm{~m} / \mathrm{s}$ in the Kara Sea

(Fig. 8) where the historical simulations show values of about $10 \mathrm{~m} / \mathrm{s}$ (not shown). 
Earth Syst. Dynam. Discuss., doi:10.5194/esd-2016-27, 2016

Manuscript under review for journal Earth Syst. Dynam.

Published: 1 August 2016

(c) Author(s) 2016. CC-BY 3.0 License.

\subsection{Clouds}

For total cloud cover there is generally a projected increase over land and a decrease over sea, especially in autumn and winter (Fig. 9). Koenigk et al. (2015) reported the largest reduction of total cloud cover in the Arctic over the Barents Sea area, related to the early disappearance of sea-ice and temperature inversion in this region. For the COSMO-CLM RCP8.5 run, the projected decrease in total winter cloud cover over this area is $2 \%$ (see Fig. 9 for the selection of the area). This is a decrease similar to the changes projected by the RCA4 runs analyzed in Koenigk et al. (2015) and in a HIRHAM RCP8.5 projection (Christensen et al., 2006) carried out for the Arctic CORDEX (Fig. 10 and Table 1).

210 While for the high level clouds there is an increase of about $15 \%$ in the RCA4 and HIRLAM5 projections, the middle cloud clover shows no clear signal and the low level clouds show a decrease, especially in the RCA4 runs (Table 1). In the simulations, the low (high) level clouds show amounts of about $90 \%(50 \%)$ of the total cloud cover in the Barents area during winter. Thus, the total cloud cover changes are dominated by a decrease in low level clouds. Note that in the COSMO-CLM, cloud fractions are not available for the standard low, medium and high pressure levels. However, the total changes over the Barents Sea are dominated by changes in the lowest cloud cover (up to $800 \mathrm{hPa}$ ) as well (not shown).

Koenigk et al. (2015) showed that reduced sea-ice and inversion in the Arctic result in opposing total cloud cover trends in the RCA4 ensemble and the driving ESM ensemble. While the RCA4 ensemble shows a decrease, the ESM ensemble projects an increase. To investigate the trends over the Barents sea, and see if the opposing trends are specific to the RCA4 model, we analyzed a set of RCM and ESM data (Table 2). Similar to the Arctic, the ESM ensemble mean (of the four driving ESMs) shows a relative change in total cloud cover of +3\% from 1971-2000 to 2071-2100 (Table 1). However, the increase in the ensemble is dominated by a relative change of $+29 \%(+16 \%$ in absolute changes) in the NorESM1-M model, while the EC-EARTH and MPI-ESM-LR model show a decrease similar to the RCM runs (Fig. 9 and Table 1). Uncertainties in winter cloud clover observations are large in the Arctic (Koenigk et al., 2015), but the NorESM1-M model is known to underestimate total cloud cover (Bentsen et al., 2012). The low amounts shown in Fig. 9 for NorESM1-M are a further sign of this limitation, and the projected trend should be considered with some caution. Neglecting the NorESM1-M data in the ESM ensemble, the resulting relative change is $-2 \%$ over the Barents sea.

Although the total cloud cover change in the RCMs might not be completely independent of the driving model (Koenigk et al., 2015), all RCM runs analyzed show similar values. This gives credibility to the RCM simulations in total cloud cover, considering the diversity of the physical schemes used in the three RCMs (e.g., for radiation, convection or microphysics, see Jacob et al., 2013), the different $\mathrm{RCM}$ grid resolutions involved $\left(0.44^{\circ}\right.$ and $\left.0.22^{\circ}\right)$ and the spread in the ESMs. 

reach a relatively warm, ice-free sea, resulting in destabilization of air. Schweiger et al. (2008) related below normal sea-ice concentrations to smaller stability (due to an absent temperature inversion) resulting in a higher convective cloud cover. Thus, in the climate projections, an increase in convective cloud cover over the Barents sea should occur in connection with the sea-ice retreat. As expected, the COMSO-CLM simulations show an increase in convective clouds in winter (Fig. 11) over the area. The increase is apparent in all layers and accompanied by a lifting of the cloud height. Note that the increase in convective clouds goes along with a decrease in total and low layer cloud cover.

With the increase of convective clouds, convective precipitation in the COSMO-CLM increases as well (Fig. 12). While in the current climate total precipitation is mostly dominated by large scale precipitation, a substantial part comes from convective activity in the future projections. This is also valid for the other RCP8.5 runs carried out for the Arctic CORDEX (Fig. 12). Contrary to the total cloud cover, the driving ESMs (including NorESM1-M) do not give opposing trends in total or convective precipitation but show an increase as well (not shown). This shows that the increasing convective activity over the Barents sea in winter is a robust signal in all RCP8.5 runs, both from regional and global models considered in this study (2).

\section{Summary and Conclusions}

The regional climate model (RCM) COSMO-CLM has been used to simulate local climate conditions over northern Scandinavia, the Barents region and Svalbard and to study potential response to a continued global warming. For this purpose, four simulations from two global earth system models (MPI-ESM-LR and EC-EARTH) have been downscaled with the COSMO-CLM to $25 \mathrm{~km}$ grid resolution.

Our evaluation of the historical COSMO-CLM simulations has revealed biases in temperature, precipitation and sea-ice extent, but overall the model realistically represents the current climate conditions when driven by the MPI-ESM-LR. Driven by EC-EARTH, the COSMO-CLM shows more pronounced biases over parts of the region due to too large sea-ice extents inherited from the global model. However, the EC-EARTH driven run still gives interesting insights on how the COSMO-CLM performs and how the projected changes are influenced by the driving model.

265 For the future, the climate projections show the strongest warming in winter in the area between the present day (1971-2000) and future (2071-2100) sea-ice border. For RCP8.5, the projected increases reach up to $20 \mathrm{~K}$, resulting in winter mean temperatures close to melting temperatures.

Similar spatial pattern as in the temperature changes are seen for changes in daily minimum and maximum temperatures, precipitation and wind, and in all scenario runs. Daily minimum temperatures show the strongest increase, daily maximum temperature the lowest, resulting in an average decrease of the daily temperature range by about $0.4 \mathrm{~K}$ in the RCP 8.5 scenario. Estimates of precipi- 

takes place in summer along the west coast of Norway and in the Arctic.

These results are in agreement with other studies covering the same area (Benestad et al., 2016; Koenigk et al., 2015; Førland et al., 2009; Vikhamar-Schuler et al., in press), including both statistical and dynamical downscaling approaches. Compared with the big ensemble of statistically downscaled models shown in Benestad et al. (2016) our projections cover a large part of the projected uncertainties. This can be attributed to the use of an ESM and scenario combination in this study, which covers weak (MPI-ESM-LR RCP2.6), moderate (MPI-ESM-LR RCP4.5) and strong (MPI-ESM-LR RCP8.5 and EC-EARTH RCP4.5) climate change signals over the target region.

For winter mean cloud cover, the COSMO-CLM projections show a general decrease over sea and an increase over land, dominated by changes in low layer clouds. Over the Barents sea, RCP8.5 projections from two other RCMs (RCA4 and HIRLAM5) show similar amounts and trends as the COSMO-CLM. In contrast, the ensemble mean of the driving ESMs shows much lower amounts and an increasing trend. This was already discussed in Koenigk et al. (2015) for the Arctic, but the reasons remained unknown. Our analyses showed that the ensemble mean is dominated by the NorESM1-M model, which gives very low total cloud cover amounts for the current climate and a strong increase for the future period. Removing the NorESM1-M projections from the ESM ensemble results in a decreasing trend in agreement with the RCM projections. Considering the differences in the RCMs, their setups and the driving ESMs, the agreement of the RCM projections for total cloud cover in the area shows that there is an added value in the RCM projections.

While a decrease is projected in the total and low layer cloud cover, the convective cloud fraction over the Barents sea increases in all vertical layers in a warmer world, together with a lifting of the cloud height and an increases in total and convective precipitation. The increase of total and convective precipitation over the Barents sea in winter is a robust signal in all RCP8.5 runs taken into account in this study (see Table 2), including both regional and global models.

Our results also support earlier findings of a strong gradient over Svalbard from south-west to north-east (Førland et al., 2009). With an increased spatial resolution a more detailed analysis for Svalbard could be carried out. Therefore, the MPI-ESM-LR driven COSMO-CLM run for the RCP8.5 scenario will be further downscaled to a convection resolving scale $\left(0.022^{\circ} \approx 2.5 \mathrm{~km}\right)$ over Svalbard for the time periods 1989-2000 and 2089-2100. The results of the current study show, that the COSMO-CLM is a suitable tool to provide the boundary conditions for the high resolution run, which will be analyzed in another study.

Acknowledgements. This work was carried out within the Adaptation Actions for a Changing Arctic (AACA) project of the Arctic Monitoring and Assessment Programme (AMAP). We acknowledge the World Climate Research Programme's Working Group on Regional Climate, and the Working Group on Coupled Modelling, former coordinating body of CORDEX and responsible panel for CMIP5. We also thank the climate modelling 
Earth Syst. Dynam. Discuss., doi:10.5194/esd-2016-27, 2016

Manuscript under review for journal Earth Syst. Dynam.

Published: 1 August 2016

(c) Author(s) 2016. CC-BY 3.0 License. (GO-ESSP). 
Earth Syst. Dynam. Discuss., doi:10.5194/esd-2016-27, 2016

Manuscript under review for journal Earth Syst. Dynam.

Published: 1 August 2016

(c) Author(s) 2016. CC-BY 3.0 License.

\section{References}

Benestad, R. E., Førland, E. J., and Hanssen-Bauer, I.: Empirically downscaled temperature scenarios for Svalbard, Atmospheric Science Letters, 3, 71-93, doi:10.1006/asle.2002.0051, 2002.

Benestad, R. E., Parding, K. M., Isaksen, K., and Mezghani, A.: Climate change and projections for the Barents region: what is expected to change and what will stay the same?, Environmental Research Letters, 11, 054 017, doi:10.1088/1748-9326/11/5/054017, 2016.

Bentsen, M., Bethke, I., Debernard, J. B., Iversen, T., Kirkevåg, a., Seland, Ø., Drange, H., Roelandt, C., Seierstad, I. a., Hoose, C., and Kristjánsson, J. E.: The Norwegian Earth System Model, NorESM1-M Part 1: Description and basic evaluation, Geoscientific Model Development Discussions, 5, 2843-2931, doi:10.5194/gmdd-5-2843-2012, 2012.

Böhm, U., Kücken, M., Ahrens, W., Block, A., Hauffe, D., Keuler, K., Rockel, B., and Will, A.: CLM - the climate version of LM: Brief description and long-term applications, Tech. Rep. 6, COSMO Newsletter, 2006

Christensen, O. B., Drews, M., Christensen, J. H., Dethloff, K., Ketelsen, K., Hebestadt, I., and Rinke, A.: The HIRHAM regional climate model version $5(\beta)$, Tech. Rep., pp. 6-17, 2006.

Day, J. J., Bamber, J. L., Valdes, P. J., and Kohler, J.: The impact of a seasonally ice free Arctic Ocean on the temperature, precipitation and surface mass balance of Svalbard, The Cryosphere, 6, 35-50, doi:10.5194/tc6-35-2012, 2012.

Dee, D. P., Uppala, S. M., Simmons, a. J., Berrisford, P., Poli, P., Kobayashi, S., Andrae, U., Balmaseda, M. a., Balsamo, G., Bauer, P., Bechtold, P., Beljaars, a. C. M., van de Berg, L., Bidlot, J., Bormann, N., Delsol, C., Dragani, R., Fuentes, M., Geer, a. J., Haimberger, L., Healy, S. B., Hersbach, H., Hólm, E. V., Isaksen, L., Kållberg, P., Köhler, M., Matricardi, M., McNally, a. P., Monge-Sanz, B. M., Morcrette, J.-J., Park, B.-K., Peubey, C., de Rosnay, P., Tavolato, C., Thépaut, J.-N., and Vitart, F.: The ERA-Interim reanalysis: configuration and performance of the data assimilation system, Quart. J. Roy. Meteorol. Soc., 137, 553-597, doi:10.1002/qj.828, 2011.

Deser, C., Knutti, R., Solomon, S., and Phillips, A. S.: Communication of the role of natural variability in future North American climate, Nature Climate Change, 2, 775-779, doi:10.1038/nclimate1562, 2012.

Dicks, L., Almond, R., McIvor, A., and Arctic Monitoring and Assessment Programme: Arctic climate issues 2011: changes in Arctic snow, water, ice and permafrost, Arctic Monitoring and Assessment Programme, Oslo, 2013

Førland, E. J., Benestad, R. E., Flatøy, F., Hanssen-Bauer, I., Haugen, J. E., Isaksen, K., Sorteberg, A., and Ådlandsvik, B.: Climate development in North Norway and the Svalbard region during 1900-2100, Report Series 128, Norsk Polarinstitutt, Troms $\emptyset, 2009$.

Giorgetta, M. A., Jungclaus, J., Reick, C. H., Legutke, S., Bader, J., Böttinger, M., Brovkin, V., Crueger, T., Esch, M., Fieg, K., Glushak, K., Gayler, V., Haak, H., Hollweg, H.-D., Ilyina, T., Kinne, S., Kornblueh, L., Matei, D., Mauritsen, T., Mikolajewicz, U., Mueller, W., Notz, D., Pithan, F., Raddatz, T., Rast, S., Redler, R., Roeckner, E., Schmidt, H., Schnur, R., Segschneider, J., Six, K. D., Stockhause, M., Timmreck, C., Wegner, J., Widmann, H., Wieners, K.-H., Claussen, M., Marotzke, J., and Stevens, B.: Climate and carbon cycle changes from 1850 to 2100 in MPI-ESM simulations for the Coupled Model Intercomparison Project phase 5, Journal of Advances in Modeling Earth Systems, 5, 572-597, doi:10.1002/jame.20038, 2013. 
Earth Syst. Dynam. Discuss., doi:10.5194/esd-2016-27, 2016

Manuscript under review for journal Earth Syst. Dynam.

Published: 1 August 2016

(c) Author(s) 2016. CC-BY 3.0 License.

Giorgi, F., Jones, C., Asrar, G. R., et al.: Addressing climate information needs at the regional level: the CORDEX framework, World Meteorological Organization (WMO) Bulletin, 58, 175, 2009.

Harris, I., Jones, P., Osborn, T., and Lister, D.: Updated high-resolution grids of monthly climatic observations - the CRU TS3.10 Dataset, International Journal of Climatology, 34, 623-642, doi:10.1002/joc.3711, 2014.

Hassol, S. J.: Impacts of a warming Arctic: Arctic climate impact assessment, Cambridge Univ. Press, Cambridge, reprinted edn., 2005.

Hazeleger, W., Wang, X., Severijns, C., Ştefănescu, S., Bintanja, R., Sterl, A., Wyser, K., Semmler, T., Yang, S., van den Hurk, B., van Noije, T., van der Linden, E., and van der Wiel, K.: EC-Earth V2.2: description and validation of a new seamless earth system prediction model, Clim. Dynam., 39, 2611-2629, doi:10.1007/s00382-011-1228-5, 2012.

Hewitt, C. D.: Ensembles-based predictions of climate changes and their impacts, Trans. Am. Geophys. Union (EOS), 85, 566-566, doi:10.1029/2004EO520005, 2004.

IPCC: Climate Change 2013: The Physical Science Basis. Contribution of Working Group I to the Fifth Assessment Report of the Intergovernmental Panel on Climate Change, Cambridge University Press, Cambridge, United Kingdom and New York, NY, USA, doi:10.1017/CBO9781107415324, 2013.

Jacob, D., Petersen, J., Eggert, B., Alias, A., Christensen, O. B., Bouwer, L. M., Braun, A., Colette, A., Déqué, M., Georgievski, G., Georgopoulou, E., Gobiet, A., Menut, L., Nikulin, G., Haensler, A., Hempelmann, N., Jones, C., Keuler, K., Kovats, S., Kröner, N., Kotlarski, S., Kriegsmann, A., Martin, E., Meijgaard, E., Moseley, C., Pfeifer, S., Preuschmann, S., Radermacher, C., Radtke, K., Rechid, D., Rounsevell, M., Samuelsson, P., Somot, S., Soussana, J.-F., Teichmann, C., Valentini, R., Vautard, R., Weber, B., and Yiou, P.: EUROCORDEX: new high-resolution climate change projections for European impact research, Reg. Environ. Change, 14, 563-578, doi:10.1007/s10113-013-0499-2, 2013.

Jones, C., Giorgi, F., and Asrar, G.: The Coordinated Regional Downscaling Experiment: CORDEX, an international downscaling link to CMIP5, CLIVAR exchanges, 56, 34-40, 2011.

Jones, C. G., Willén, U., Ullerstig, A., and Hansson, U.: The Rossby Centre regional atmospheric climate model part I: model climatology and performance for the present climate over Europe, AMBIO, 33, 199-210, 2004.

Kessler, E.: On the continuity and distribution of water substance in atmospheric circulations, Atmos. Res., 38, 109 - 145, doi:10.1016/0169-8095(94)00090-Z, 1995.

Koenigk, T., Berg, P., and Döscher, R.: Arctic climate change in an ensemble of regional CORDEX simulations, Polar Res., 34, 1-19, doi:10.3402/polar.v34.24603, 2015.

Koldunov, N. V., Stammer, D., and Marotzke, J.: Present-day arctic sea ice variability in the coupled ECHAM5/MPI-OM model, J. Climate, 23, 2520-2543, doi:10.1175/2009JCLI3065.1, 2010.

385 Kotlarski, S., Keuler, K., Christensen, O. B., Colette, a., Déqué, M., Gobiet, a., Goergen, K., Jacob, D., Lüthi, D., van Meijgaard, E., Nikulin, G., Schär, C., Teichmann, C., Vautard, R., Warrach-Sagi, K., and Wulfmeyer, V.: Regional climate modeling on European scales: a joint standard evaluation of the EURO-CORDEX RCM ensemble, Geoscientific Model Development, 7, 1297-1333, doi:10.5194/gmd-7-1297-2014, 2014.

Lindsay, R., Wensnahan, M., Schweiger, A., and Zhang, J.: Evaluation of seven different atmospheric reanalysis 390 products in the arctic, J. Climate, 27, 2588-2606, doi:10.1175/JCLI-D-13-00014, 2014.

Manabe, S. and Stouffer, R. J.: Sensitivity of a global climate model to an increase of $\mathrm{CO} 2$ concentration in the atmosphere, J. Geophys. Res.-Oceans, 85, 5529-5554, doi:10.1029/JC085iC10p05529, 1980. 
Earth Syst. Dynam. Discuss., doi:10.5194/esd-2016-27, 2016

Manuscript under review for journal Earth Syst. Dynam.

Published: 1 August 2016

(c) Author(s) 2016. CC-BY 3.0 License.

Moss, R. H., Edmonds, J. A., Hibbard, K. A., Manning, M. R., Rose, S. K., Van Vuuren, D. P., Carter, T. R., Emori, S., Kainuma, M., Kram, T., et al.: The next generation of scenarios for climate change research and assessment, Nature, 463, 747-756, doi:10.1038/nature08823, 2010.

Rayner, N. A., Parker, D. E., Horton, E. B., Folland, C. K., Alexander, L. V., Rowell, D. P., Kent, E. C., and Kaplan, A.: Global analyses of sea surface temperature, sea ice, and night marine air temperature since the late nineteenth century, J. Geophys. Res.-Atmospheres, 108, doi:10.1029/2002JD002670, 4407, 2003.

Rienecker, M. M., Suarez, M. J., Gelaro, R., Todling, R., Bacmeister, J., Liu, E., Bosilovich, M. G., Schubert, S. D., Takacs, L., Kim, G.-K., Bloom, S., Chen, J., Collins, D., Conaty, A., da Silva, A., Gu, W., Joiner, J., Koster, R. D., Lucchesi, R., Molod, A., Owens, T., Pawson, S., Pegion, P., Redder, C. R., Reichle, R., Robertson, F. R., Ruddick, A. G., Sienkiewicz, M., and Woollen, J.: MERRA: NASA's Modern-Era Retrospective Analysis for Research and Applications, J. Climate, 24, 3624-3648, doi:10.1175/JCLI-D-11-00015.1, 2011.

Ritter, B. and Geleyn, J. F.: A comprehensive radiation scheme for numerical weather prediction models with potential applications in climate simulations, Mon. Weather Rev., 120, 303-325, doi:10.1175/15200493(1992)120<0303:ACRSFN>2.0.CO;2, 1992.

Rockel, B., Will, A., and Hense, A.: The regional climate model COSMO-CLM (CCLM), Meteor. Z., 17, 347 348, doi:10.1127/0941-2948/2008/0309, 2008.

Roeckner, E., Bäuml, G., Bonaventura, L., Brokopf, R., Esch, M., Giorgetta, M., Hagemann, S., Kirchner, I., Kornblueh, L., Manzini, E., Rhodin, A., Schlese, U., Schulzweida, U., and Tompkins, A.: The atmospheric general circulation model ECHAM 5. PART I: Model description, Max-Planck-Institute for Meteorology report 349, http://hdl.handle.net/11858/00-001M-0000-0012-0144-5, 2003.

Rummukainen, M.: State-of-the-art with regional climate models, Wiley Interdisciplinary Reviews: Climate Change, 1, 82-96, doi:10.1002/wcc.8, 2010.

Samuelsson, P., Jones, C. G., Willén, U., Ullerstig, A., Gollvik, S., Hansson, U., Jansson, C., Kjellström, E., Nikulin, G., and Wyser, K.: The Rossby Centre Regional Climate model RCA3: model description and performance, Tellus A, 63, 4-23, doi:10.1111/j.1600-0870.2010.00478.x, 2011.

Schrodin, E. and Heise, E.: A New Multi-Layer Soil Model, Tech. Rep. 2, COSMO Newsletter, 2002.

Schweiger, A. J., Lindsay, R. W., Vavrus, S., and Francis, J. A.: Relationships between Arctic sea ice and clouds during autumn, J. Climate, 21, 4799-4810, doi:10.1175/2008JCLI2156.1, 2008.

Screen, J. a. and Simmonds, I.: The central role of diminishing sea ice in recent Arctic temperature amplification., Nature, 464, 1334-1337, doi:10.1038/nature09051, 2010.

Tiedtke, M.: A comprehensive mass flux scheme for cumulus parameterization in large-scale models, Mon. Weather Rev., 117, 1779-1800, doi:10.1175/1520-0493(1989)117<1779:ACMFSF>2.0.CO;2, 1989.

van Vuuren, D. P., Edmonds, J., Kainuma, M., Riahi, K., Thomson, A., Hibbard, K., Hurtt, G. C., Kram, T., Krey, V., Lamarque, J.-F., Masui, T., Meinshausen, M., Nakicenovic, N., Smith, S. J., and Rose, S. K.: The representative concentration pathways: an overview, Climatic Change, 109, 5-31, doi:10.1007/s10584-0110148-z, 2011.

Vikhamar-Schuler, D., Isaksen, K., Haugen, J. E., Tømmervik, H., Luks, B., Schuler, T. V., and Bjerke, J. W.: 
Earth Syst. Dynam. Discuss., doi:10.5194/esd-2016-27, 2016

Manuscript under review for journal Earth Syst. Dynam.

Published: 1 August 2016

(c) Author(s) 2016. CC-BY 3.0 License.
Earth System

Dynamics

Discussions

(c) (i)

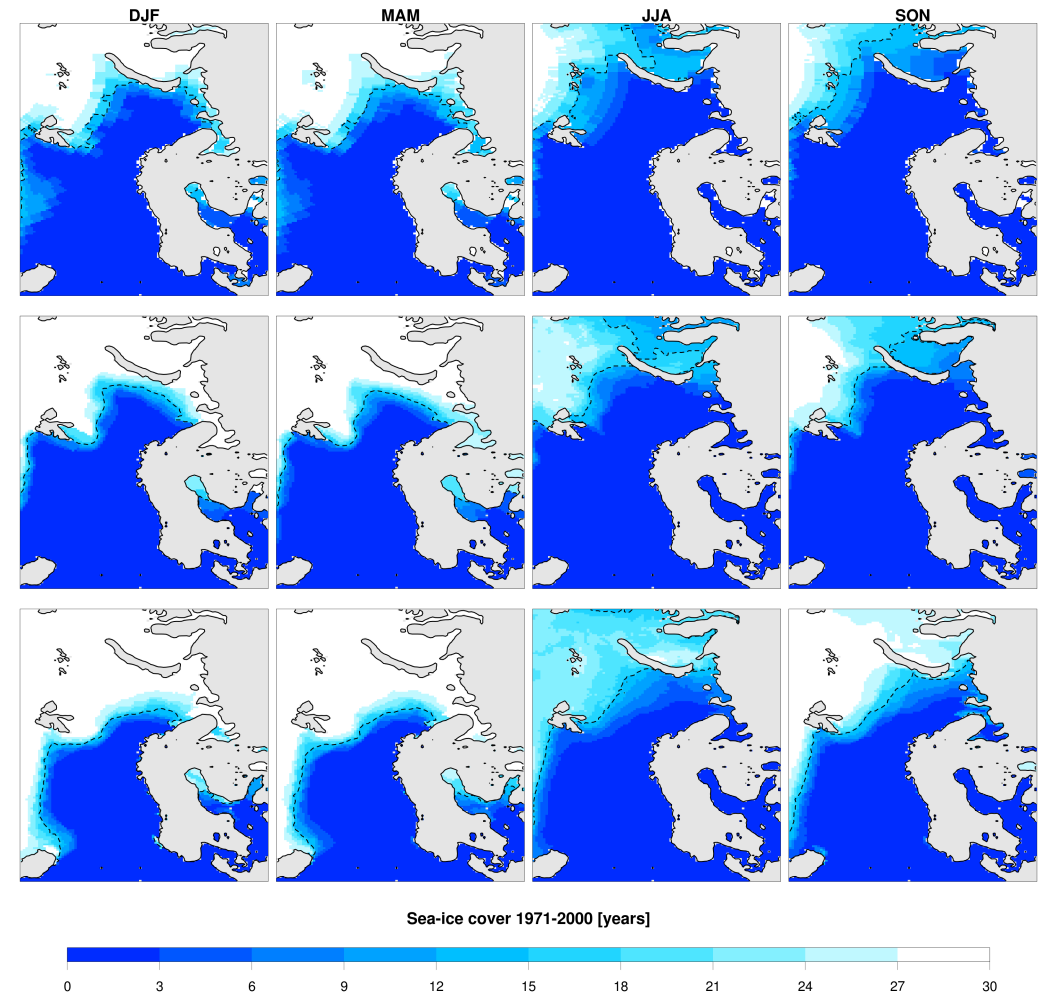

Figure 1. Number of years covered by sea-ice in the time period 1971-2000 derived from observations (top), the COSMO-CLM driven by MPI-ESM-LR (middle) and driven by EC-EARTH (bottom). The dashed lines correspond to the mean sea-ice extent (sea-ice cover on 15 years in the period 1971-2000). 
Earth Syst. Dynam. Discuss., doi:10.5194/esd-2016-27, 2016

Manuscript under review for journal Earth Syst. Dynam.

Published: 1 August 2016

(c) Author(s) 2016. CC-BY 3.0 License.

\section{(c) (1)}
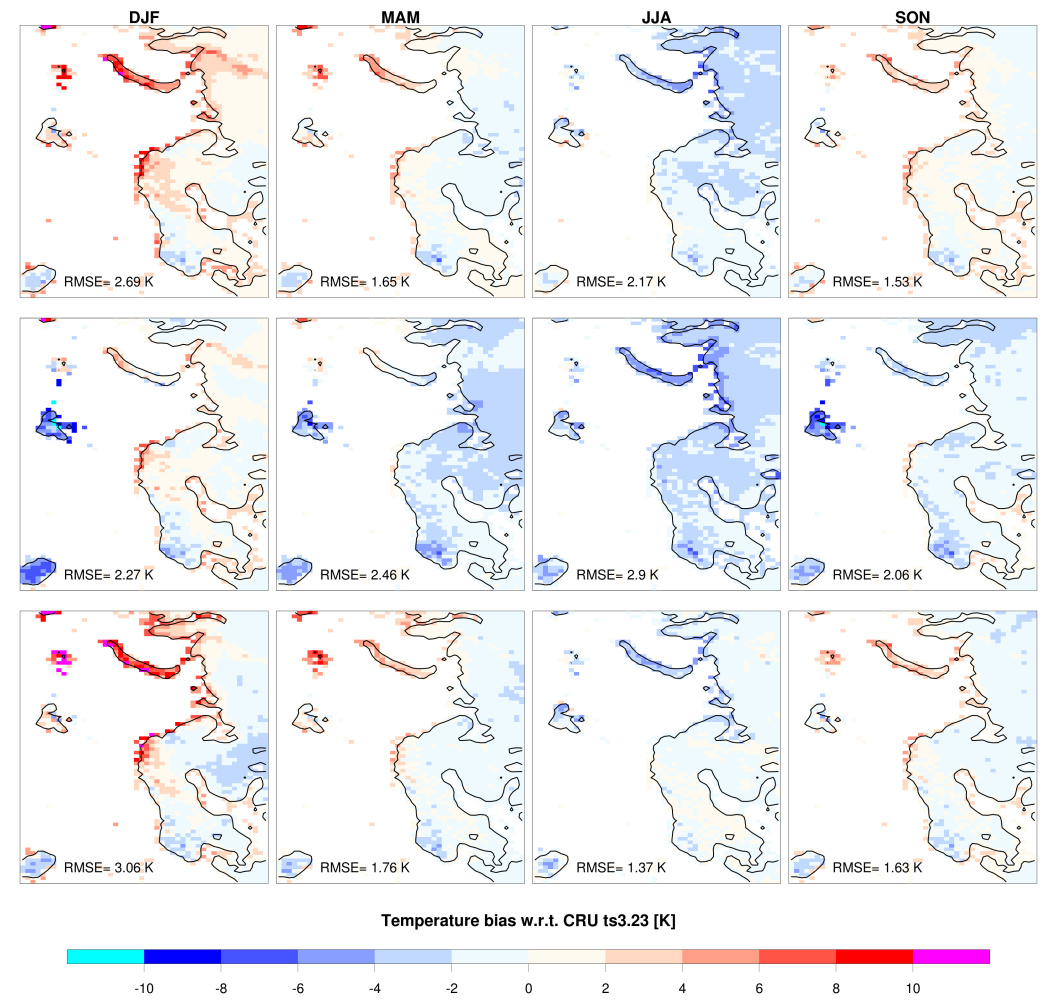

Figure 2. Temperature bias compared with CRU observations [K] for the COSMO-CLM driven by MPI-ESMLR (top), COSMO-CLM driven by EC-EARTH (middle) and the MERRA reanalysis. 
Earth Syst. Dynam. Discuss., doi:10.5194/esd-2016-27, 2016

Manuscript under review for journal Earth Syst. Dynam.

Published: 1 August 2016

(c) Author(s) 2016. CC-BY 3.0 License.
Earth System

Dynamics

Discussions

(c) (1)
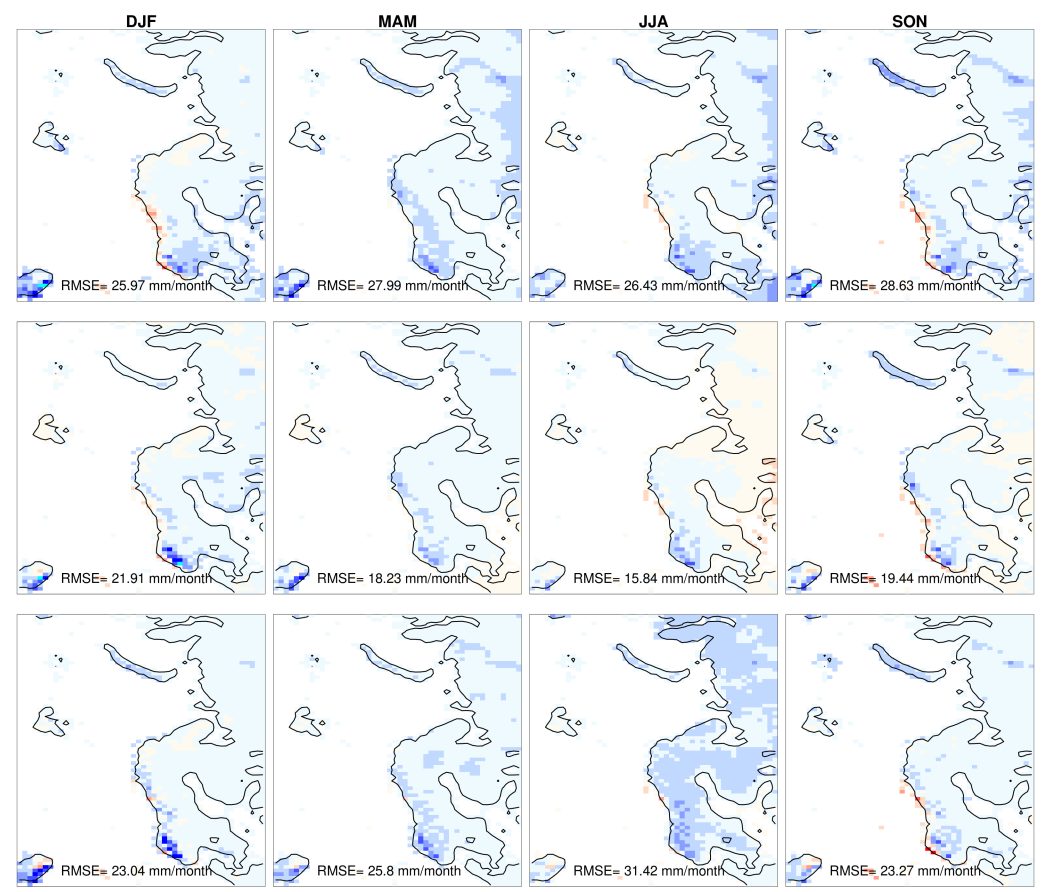

Precipitation bias w.r.t. CRU ts $3.23[\mathrm{~mm} / \mathrm{month}]$

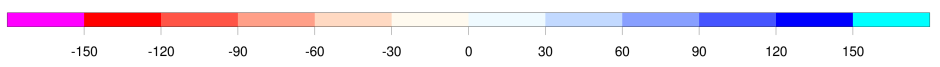

Figure 3. As for Fig. 2, but for precipitation [mm/month]. 
Earth Syst. Dynam. Discuss., doi:10.5194/esd-2016-27, 2016

Manuscript under review for journal Earth Syst. Dynam.

Published: 1 August 2016

(c) Author(s) 2016. CC-BY 3.0 License.
Earth System

Dynamics

Discussions

(c) (i)
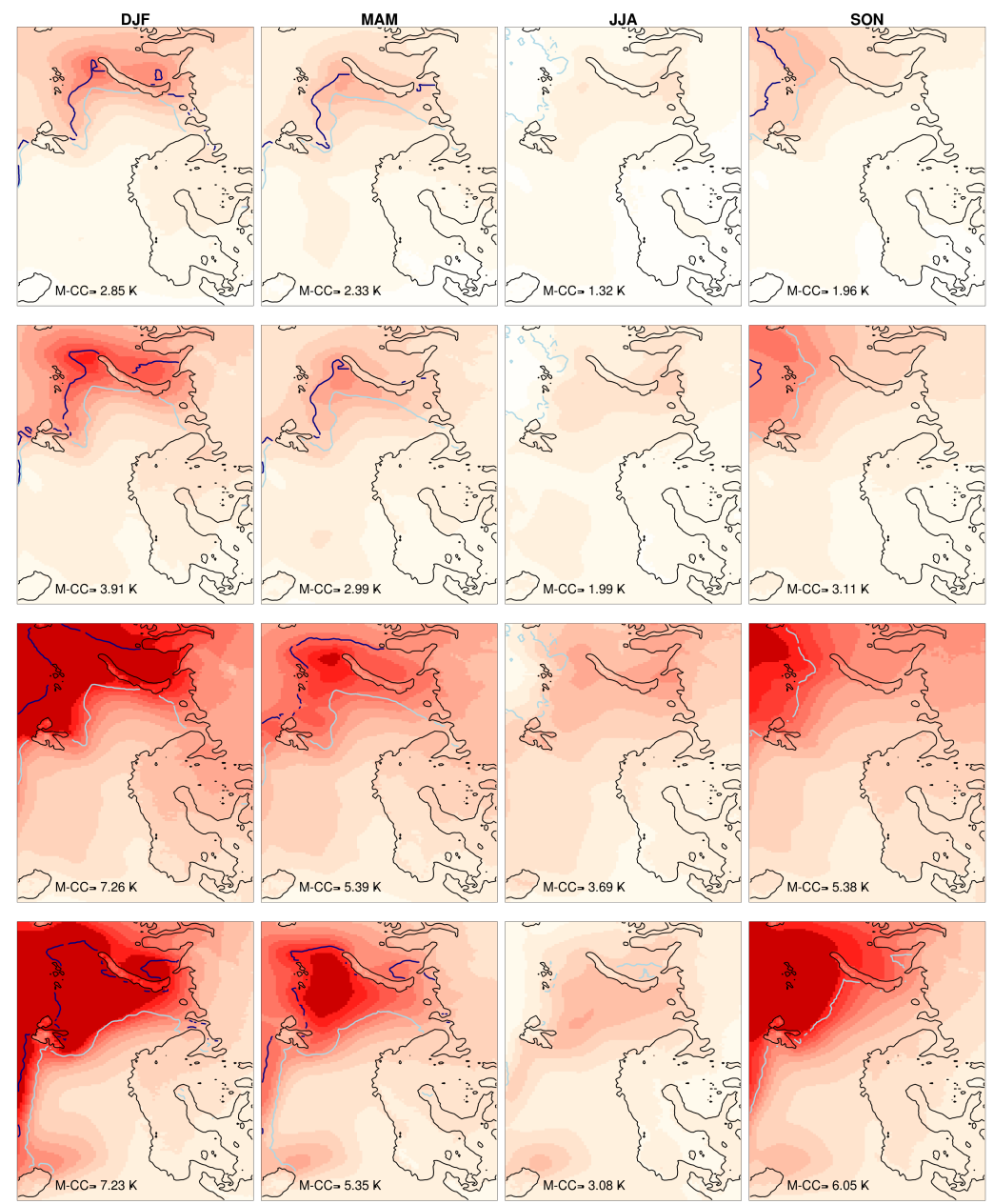

$2 m$ temperature change $[K], 2071-2100$ vs. 1971-2000

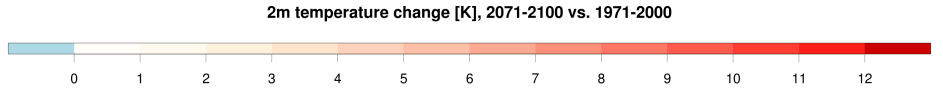

Figure 4. Projected seasonal 2m temperature changes [K] for the time period 2071-2100 relative to 1971-2000. The four rows show the COSMO-CLM results driven by MPI-ESM-LR RCP2.6, RCP4.5 and RCP8.5 and ECEARTH RCP4.5 (from top to bottom). The dark and light blue lines indicate the northern extent of an ice-free sea on at least $20 \%$ of the year in the future and historical period respectively. The numbers at the bottom left give the mean climate change signal over the domain shown. 
Earth Syst. Dynam. Discuss., doi:10.5194/esd-2016-27, 2016

Manuscript under review for journal Earth Syst. Dynam.

Published: 1 August 2016

(c) Author(s) 2016. CC-BY 3.0 License.
Earth System

Dynamics

Discussions

(c) (1)
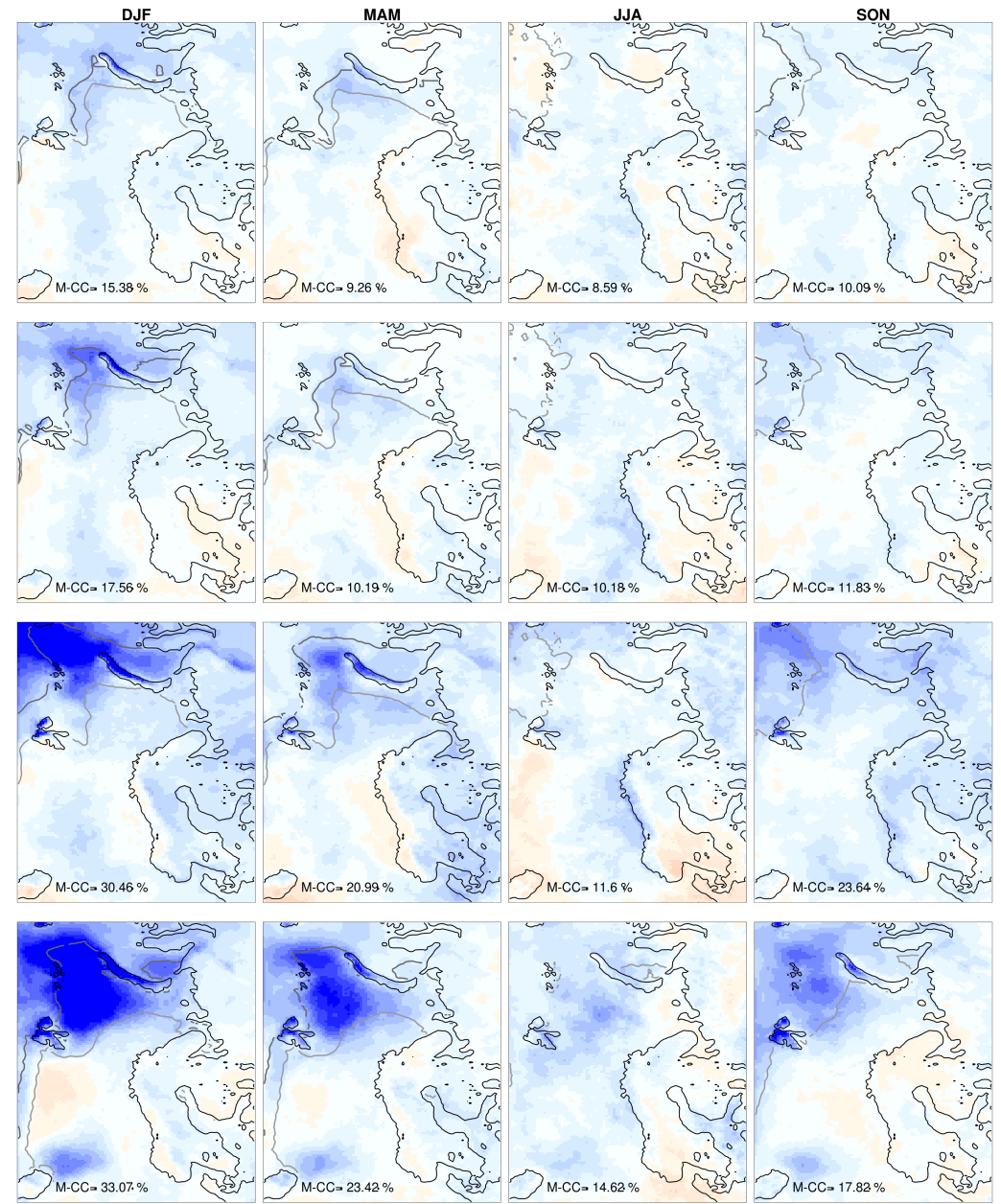

Relative precipitation change [\%], 2071-2100 vs. $1971-2000$

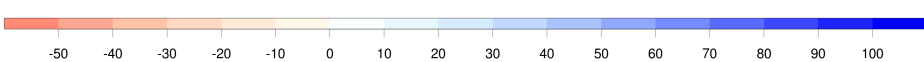

Figure 5. As Fig. 4, but for the relative precipitation change [\%]. 
Earth Syst. Dynam. Discuss., doi:10.5194/esd-2016-27, 2016

Manuscript under review for journal Earth Syst. Dynam.

Published: 1 August 2016

(c) Author(s) 2016. CC-BY 3.0 License.
Earth System

Dynamics

Discussions

(c)

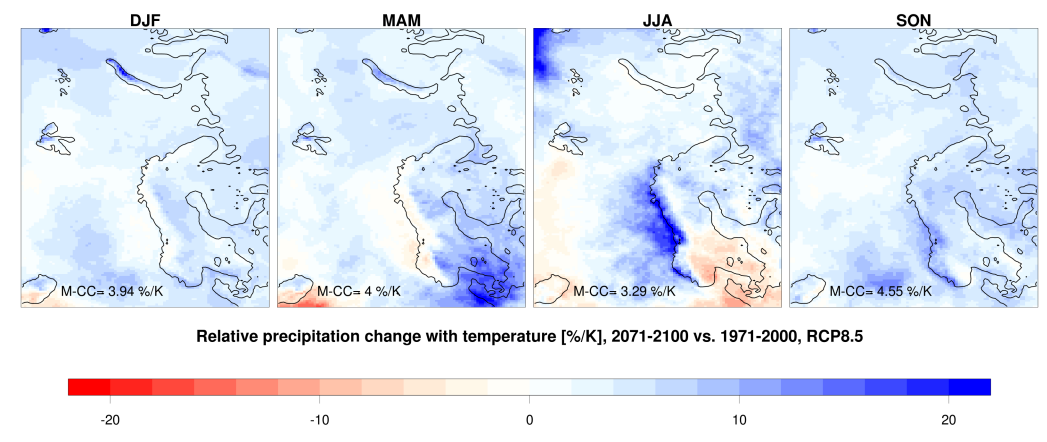

Figure 6. Seasonal relative precipitation sensitivities $[\% / \mathrm{K}]$ for the RCP8.5 scenario.

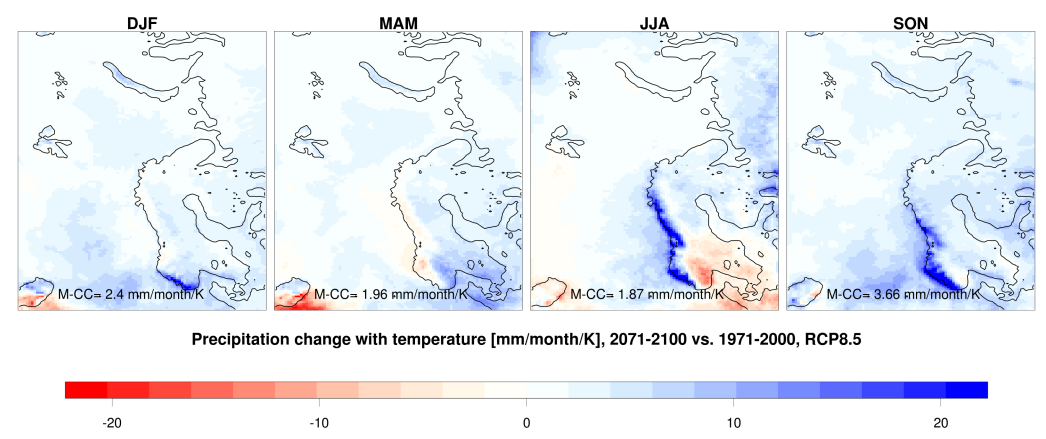

Figure 7. As Fig. 6 but for the absolute precipitation sensitivities [mm/month/K].

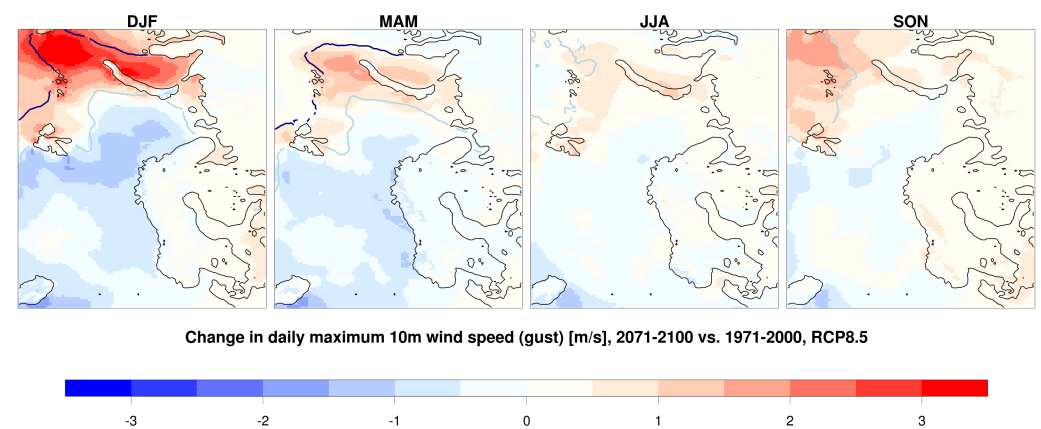

Figure 8. As Fig. 4 but for the daily maximum $10 \mathrm{~m}$ wind speed change $[\mathrm{m} / \mathrm{s}]$ and the RCP8.5 scenario only. 
Earth Syst. Dynam. Discuss., doi:10.5194/esd-2016-27, 2016

Manuscript under review for journal Earth Syst. Dynam.

Published: 1 August 2016

(c) Author(s) 2016. CC-BY 3.0 License.
Earth System

Dynamics

Discussions

(c) (i)

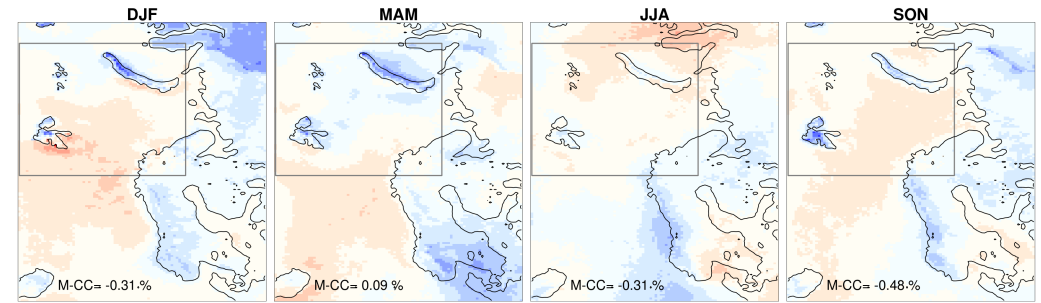

Relative change of total cloud cover [\%], 2071-2100 vs. 1971-2000

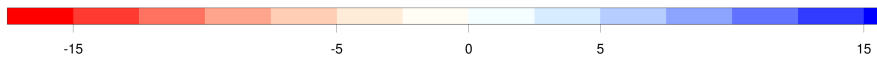

Figure 9. As Fig. 8, but for relative changes in total cloud cover [\%]. The rectangle indicates the area selected as Barents sea region.

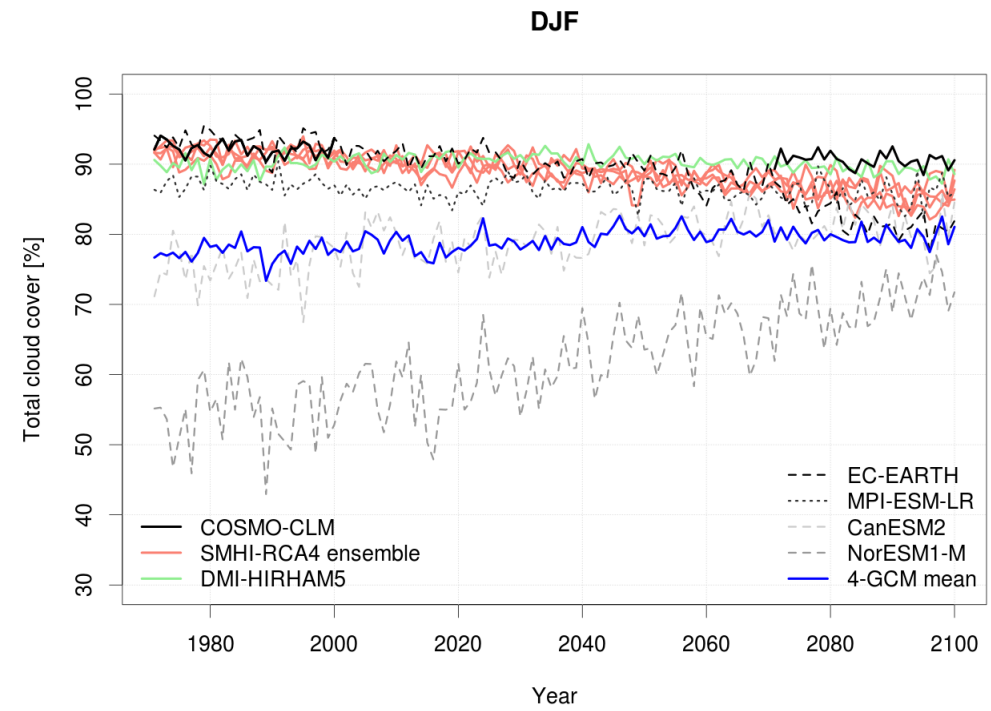

Figure 10. Time series of total cloud cover over the Barents sea region in winter [\%] for different RCM and ESM RCP8.5 runs. The COSMO-CLM was driven by MPI-ESM-LR, RCA4 by four ESMs and HIRHAM5 by EC-EARTH. 
Earth Syst. Dynam. Discuss., doi:10.5194/esd-2016-27, 2016

Manuscript under review for journal Earth Syst. Dynam.

Published: 1 August 2016

Earth System

Dynamics

Discussions

(c) Author(s) 2016. CC-BY 3.0 License.

(c) (P)

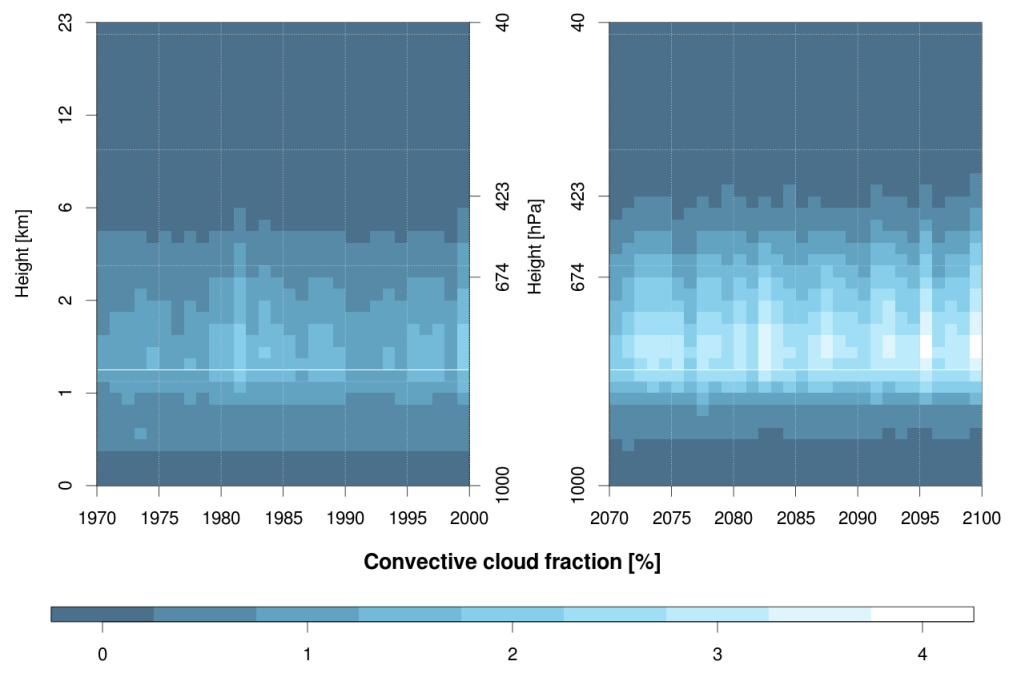

Figure 11. Convective cloud fraction over the Barents sea region in winter [\%] for the COSMO-CLM RCP8.5 run.

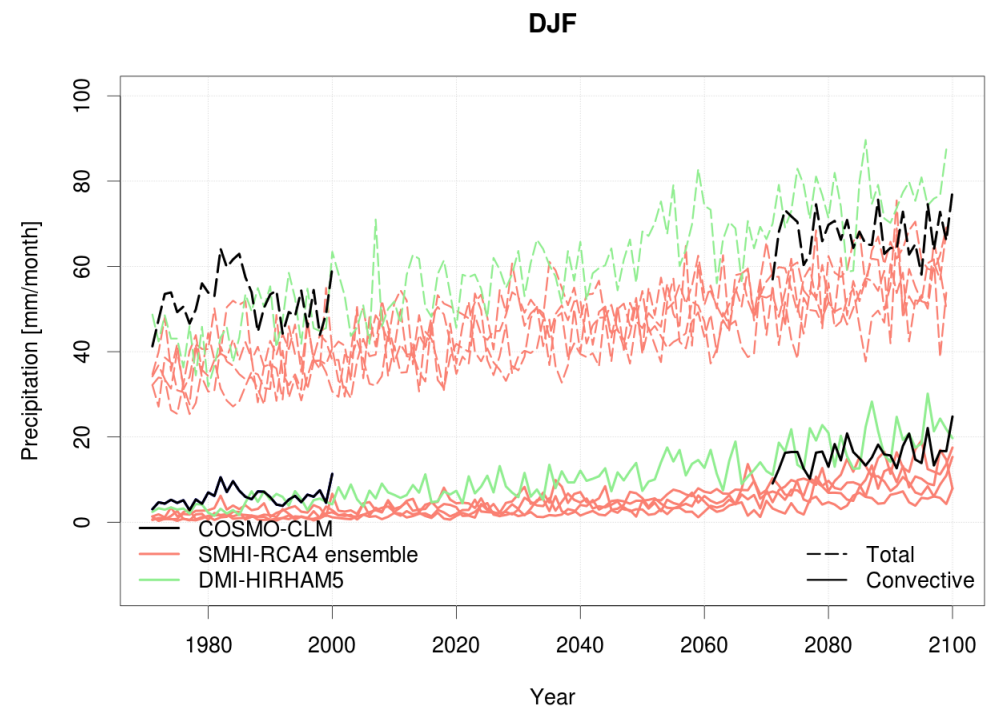

Figure 12. As Fig. 10, but for convective and total precipitation [mm/month] and RCMs only. 
Earth Syst. Dynam. Discuss., doi:10.5194/esd-2016-27, 2016

Manuscript under review for journal Earth Syst. Dynam.

Published: 1 August 2016

(c) Author(s) 2016. CC-BY 3.0 License.

Table 1. Relative cloud cover changes from $1971-2000$ to $2071-2100$ for different RCM and ESM RCP8.5

runs.

\begin{tabular}{lllllll}
\hline $\begin{array}{l}\text { RCM } \\
\text { driving ESM }\end{array}$ & RCA4 & RCA4 & RCA4 & RCA4 & HIRHAM5 & COSMO-CLM \\
\hline CanESM2 & EC-EARTH & MPI-ESM-LR & NorESM1-M & EC-EARTH & MPI-ESM-LR \\
\hline Total cloud cover & $-7 \%$ & $-7 \%$ & $-5 \%$ & $-4 \%$ & $-0.6 \%$ & $-2 \%$ \\
High $(<440 \mathrm{hPa})$ & $+17 \%$ & $+17 \%$ & $+14 \%$ & $+14 \%$ & $+13 \%$ & $-0.9 \%$ \\
Middle $(440-680 \mathrm{hPa})$ & $+2 \%$ & $-0.6 \%$ & $+2 \%$ & $+3 \%$ & $-1 \%$ & \\
Low $(>680 \mathrm{hPa})$ & $-14 \%$ & $-16 \%$ & $-11 \%$ & $-9 \%$ & $-1 \%$ \\
\hline ESM & CanESM2 & EC-EARTH & MPI-ESM-LR & NorESM1-M & 4-ESM mean \\
\hline Total cloud cover & $+7 \%$ & $-12 \%$ & $-2 \%$ & $+29 \%$ & $+3 \%$ & \\
\hline
\end{tabular}

Table 2. Overview of the RCMs (top) and ESMs (bottom) providing data to this study.

\begin{tabular}{lll}
\hline Model & Modelling institute & Data source \\
\hline COSMO-CLM & Norwegian Meteorological Institute & own \\
HIRHAM5 & Danish Meteorological Institute & CORDEX \\
RCA4 & Swedish Meteorological and Hydrological Institute & CORDEX \\
\hline CanESM2 & Canadian Centre for Climate Modelling and Analysis & CMIP5 \\
EC-EARTH & EC-EARTH consortium & CMIP5 \\
MPI-ESM-LR & Max Planck Institute for Meteorology & CMIP5 \\
NorESM1-M & Norwegian Climate Centre & CMIP5 \\
\hline
\end{tabular}

